\title{
Recognition of Learner and Teacher in Rural Junior-High School for the 2015 Revised Curriculum of South Korea
}

\author{
JuSeuk Kim \\ Assistant Professor, Dept. of Liberal Art, Joongbu University \\ PO Box 32713, Chubu-myeon 201, Geumsan-gun, Chungnam, South Korea \\ Tel: 82-010-2277-0653Ｅ-mail: juskim@jbm.ac.kr
}

Received: May 9, 2019

Accepted: May 26, 2019

Published: June 5, 2019

doi:10.5296/gjes.v5i1.14761

URL: https://doi.org/10.5296/gjes.v5i1.14761

\begin{abstract}
This study examines students' perceptions of the revision of the 2015 curriculum and draws out a task to create a positive impact on career paths of the students. For this purpose, this study selected three autonomous junior high schools in rural areas of Jeonbuk province and conducted questionnaires on students and teachers. In particular, the results of the survey on the policy of free semester, integration policy of the humanities track and science track, and career education policy showed the students' positive expectation for the revision of the curriculum in 2015. Therefore, the following survey results were obtained. First, we could confirm a very positive reaction in the free semester. Second, there is a difference in the pros and cons of the autonomous junior high schools regarding the integration policy. In particular, the integration policy of the humanities track and science track shows that there is a positive expectation for career advancement. On the contrary, the perception that there is a concern about the effect on career is also investigated. Third, we could confirm the general lack of understanding about career education policy. Therefore, it can be confirmed that it is necessary to secure the justification for future career education, to promote active career education, and to follow-up policy for continuous career activities. Therefore, this paper suggests more active promotion and approach related to career policy.
\end{abstract}

Keywords: 2015 revised curriculum, liberal semester system, combination policy of the liberal arts and natural sciences, career education, autonomous junior high school 


\section{Preface}

South Korean education has played a role of crucial foundation for the development of national economic society over the past half century. However, on one aspect, the educational regulation that excessively focuses on college entrance and the overflowing academic-oriented social perception are acting as obstacles in raising diversified and creative talents of the 21 st century. Hence, to keep up especially with the development of the knowledge economy and the growing aging society, in overall, to respond with the changing future society, the 2015 Reformed Educational Process was enforced.

The core of the South Korean 2015 Reformed Educational Process is that the students foster basic knowledge through school education and attempt to grow them into creativity fused talents with liberal imagination and creativity of science technologies. Thus, the basic direction of the 2015 Reformed Educational Process can be said to be 'nurturing creativity fused talents' to keep up with the changing knowledge economic society, while maintaining 'nurturing creative talents' pursued by the 2009 Reformed Education Process.

Such 2015 Reformed Educational Process laid out the major fundamental principles. First, the principle of 'strengthening education for cultivating humanities society science technological basic knowledge', aims to foster basic knowledge and the integrated way of thinking. Second, the principle of 'educational process development to nurture dreams and talents of the students' aims on opening various optional modules that consider career choices of the students. The third principle lays out the 'curriculum development capable of nurturing the requirements of future society', and finally, lays out the fundamental principle of 'improvising the general educational regulation in connection with the educational process' (Ministry of Education, 2015).

The biggest feature of such 2015 Reformed Educational Process is the direction of fostering creativity fused talents and core competence etc. To achieve this, understanding of the students and teachers, regarding the personality, direction, contents etc of the 2015 Reformed Educational Process, is imperative. Especially in the junior high school educational process, more active career education can be conducted through the implementation of free-semester system, and the key would be settling of free-semester system in the junior high school educational process through accurate guidance on the operation methods of the free-semester system. Also, in the case of high schools, cultivation of fundamental humanities and basic academic guarantee through the liberal arts and natural sciences combined educational process is the major feature. The essential point would be finding the right balance between general optional modules and career optional modules to ensure that the implementation of common module does not go against the purpose of optional educational process.

In such circulation, attempt to improvise the problems of national educational procedure and college entry, through the combination of liberal arts and natural sciences, is in process, but the concrete effectiveness is not certain yet. Also, several reports and research studies on the new educational process has been made, but there is still a need to look into the essential particulars of the 2015 Reformed Educational Process as recognized by the students, especially into how well the combined type policy of liberal arts and natural sciences has 
been delivered to the students, as it directly influences the students. The combined type policy of liberal arts and natural sciences is a policy that aims to reform the foundation of education through providing school education without division of liberal arts and natural sciences and help the students to nurture into creativity convergent talents.

Thus, it is necessary to look into the perception on the combination of liberal arts and natural sciences and career education, and accordingly find out what efforts are required for the 2015 Reformed Educational Process to be effectively implemented. However, various research studies have been conducted, but studies focusing only on the choice between liberal arts and natural sciences have limitation of lacking student's expectations on the career perceptions, who are connected to the 2015 Reformed Educational Process.

Based on the inspection and analysis information on the policy direction of school education aiming for a change in the new educational system, for the 2015 Reformed Educational Process to present a meaningful direction for the students, it is especially imperative to figure out student's perception in school sites and carry out in practice in junior high and high schools. Therefore, the purpose of this research is investigating rightly direction of the operation of educational policy through conducting awareness investigation on the freshers and sophomores of university and teachers regarding the combinational education process of liberal arts and natural sciences.

\section{Preceding Research}

There have been many studies on the South Korean reformed educational process. Many discussions have been made, especially on the biggest features of the 2015 Reformed Educational Process, the combined type policy and course selection, and provided the pro and con analysis of the current educational procedure and future improvements that are needed. Chang Won Kim (2015) researched on the application and the follow-up support of the reformed high school educational process. It was confirmed that the 2015 Reformed High School Educational Process can be put into various forms depending on the optional subjects chosen after selection of core subjects, and an overall follow-up measure is essential to achieve the major purpose of the 2015 Reformed High School Educational Process. Hence, the overall and flexible follow-up educational process measures of the educational process on the stronghold schools, online classes, Education Office operation etc were proposed in order to reduce the difference in choices per school and range of course length for the efficient operation of core and optional subjects. In the studies by Kwang Hee Cho, Ji Sun Choi, Hyang Sook Cho (2012), research was done on course selection and university major choices, as well as the reason for choosing sciences and mathematics courses etc. Students considered interests, grades, aptitude for applicable courses, future jobs etc as the reasons for choosing mathematics and science for university degree and high school modules. Also, the research outcome showed that $48.8 \%$, amounting nearly half of the students, chose the course due to math and science. Moreover, the most determinant factor for the high school students choosing science related modules was level of interest (44.9\%), but choices determined by whether the relevant course is provided in schools and the university admissions regulation also took a large percentage $(27.8 \%)$. Furthermore, $44.7 \%$ of the students who gave up on 
their first-choice subjects was due to unopened course or disadvantages in university admissions etc. In the decision-making process of math courses, many highly considered the College Scholastic Ability Test and school records influence, opening of the course and the same external conditions. Such research results showed that the admissions policy based on the student's school grades limits the choice in math and science courses. The research by Mi Sun Yoon (2009) explored the influential factors of student's choices on courses among course interests, career efficiency, school grades etc. According to the research results, among liberal arts and natural sciences selection, for students choosing natural sciences, relatively clear standards, including grades and course interests etc, were applied from the initial decision stage. Also, the decision factors for science courses were, 'personal interests' and 'school grades' for female students and 'personal interests' and 'self-efficiency for machines and data processing related career path' for male students. Study by Seung Hyun Choi and Soon Hee Song (1993) analyzed high school student's liberal arts and natural sciences selections based on psychological behavior theory. In this research, students made decisions on the subjects depending on the courses that they like or their actions rather than external pressure or other's opinions. Furthermore, students wishing math and science related careers often chose natural sciences, but the students choosing liberal arts often rooted from wanting to avoid difficult subjects. Hoo Jo Hong (2015) explored the issues related to liberal arts and natural sciences combination in the 2015 Reformed Educational Process and proposed a direction for combining process of liberal arts and natural sciences for the long side of improving high school educational process. The research on the combined type educational process of liberal arts and natural sciences for high school teachers and education related officials, emphasized on the development need in the direction of guaranteeing gradual learning opportunities per career during high school education. High school teachers especially showed traits of maintaining the existing social subjects and subject segregation. However, other education related officials emphasized the solution method for such traditional segregation through the combination process of liberal arts and natural sciences.

In addition, several studies were done on respective subjects in the combined educational process. Research by Hyun Ji Lee, Kyung Hee Lee and Byeong Soon Choi (2015) researched on the integrated science education to grow scientific knowledge of all students and composed combined type educational process of liberal arts and natural sciences in science departments. Eung Hyun Kim (2015) studied social course integrated education of combined type educational process in the 2015 Reformed Educational Process and actively sought to find the solution in the gap between the ideal and reality with many areas, especially in the social subject integrated education. Young Hee Yang (2015) studied Korean language course integrated process from the 2015 Reformed Educational Process. Although the integrated educational process policy shows focus on the combination of social and science courses, Yang attempted to use such opportunity to bring changes into practical and consumer central educational process in the Korean language course. Under such purpose, research was proceeded centrally on the detailed grammar area in the course. Kyu Hoon Kim's (2014) study focused on the Korean language course in the integrated educational process and researched centrally on the problem of the Korean language course subject setting. Focus was on particularly confirming the 'subject system' in the discussion on restructuring integrated 
Korean language course educational process and contemplated the validity of subject choosing in the integrated Korean language course educational process. Chul Gi Cho (2016) proceeded research centrally on geography course in the integrated educational process, focusing especially on finding integrated education to grow integrated mindset within geography course, but emphasized that integration within the geography must be pre-established.

Besides these, researches compared with foreign examples of integrated educational process. From this, advantages and disadvantages of the South Korean educational process was compared and proposed future directions. Jin Dong Park (2013) suggested an implication about the integrated education through the Canadian case. In the 4 years length high school in Toronto, certain standard of grades is required for graduation and perform essential grades policy for general university admissions. However, most students choose modules depending on their preference not future path and the number of subjects for the departments only differ by one or two. Also, in universities, major is chosen regardless of liberal arts or natural sciences and through the research analysis, combination of liberal arts and natural sciences will not create any problem in studying major in universities. Gao Shan (2015) compared the integrated liberal arts and natural sciences educational process policy between China and South Korea. Both countries proposed the combination of liberal arts and natural sciences aiming to alleviate the imbalanced knowledge obtained due to division in liberal arts and natural sciences and nurture integrated talent as required by the current society. Also, it was analyzed that in the case of Korea, in the side of educational process, combination of liberal arts and natural sciences is most prioritized, whereas in China, changes are brought through amendments in students Scholastic Ability Test rather than a big reform in the entire educational process. Moreover, three combination models of 'commonness over diversity proposal', 'process fragmentation method' and 'customized educational process operation method' were observed and it has been analyzed that both South Korea and China pursued the 'customized educational process operation method'.

Regarding the integrated educational process, research on university life and career after graduation was also conducted. Ho Joong Bae (2015) analyzed the difference in university life and employability following the high school subject selection (liberal arts and natural science). First, for subjects that were not chosen, $15 \%$ was due to low grades and lack of preference. Especially for liberal arts, choices that were made out of wishes to avoid math and science subjects instead of following aptitude and interests were not few. University attending period per high school did not show any interrelation, and for reselection of degree, liberal arts courses showed higher number, reflecting the satisfaction for the course. However, in employment wise, natural science graduates showed higher results in terms of first job wages, job employment and maintaining job. Especially after the currency crisis, job maintenance rate and rise in social status possibility and wages standards rated lower for natural sciences graduates. Mi Mi Lee (2014) researched the direction of the liberal arts university education in the liberal arts and natural science combined type-high school educational process era. Comparison analysis on the liberal arts university education in the flow of integrated education era policy and reincarnation of departmental system in 
universities policy, the analysis results showed 2 forms of university educational process. First, as liberal education, liberal arts was proceeded as equal liberal arts educational process operation, regardless of major, and second, universities that differentiate liberal arts educational process depending on the major, which comparatively emphasizes more over liberal arts education as the fundamental knowledge education of the major. Research by Hoon Ho Kim, Han Sol Woo, Han Gil Kim and Byul Hee Kim (2015) analyzed the relationship between double major completion and employability. Based on the results, double degree graduates have higher chances of getting a job within 18 and 24 months and higher monthly wages for their first job. Also, humanities department graduates with double major in other major or business field are paid higher wages than graduates with single humanities degree and it was discovered that higher satisfactory rate of students for career-related counselling and support policy provided in their graduated universities led to higher employment rates. Research by Ho Joong and Tae Soo Park (2014) performed an economic analysis on the double major graduates of a 4-year period university. According to the research results, $13.2 \%$ of the graduates completed a double major, and the humanities and social sciences students engaged in double major more than the natural sciences students. Double major students have relatively longer university period than single major students, and the highest percentage of double major was business management and economy departments. The results of double major decision differed in majors, and it was analyzed that business management and economy double major especially had positive influence in the initial labor market participation process.

Besides these, there have been studies on career decision and optional modules, and Sun Young Ahn and Kyung Sang Lee (209) analyzed the determinant factor of career decision of teenagers focusing centrally on the subject choice from junior high to high school stage, and it showed that the possibilities of choosing academic high school increased with monthly income, education ambition and academic achievement. Moreover, it can be seen that the academic students have more positive experience in adapting to school, interests in school education, relationship with teachers, self-concept and life satisfaction compared to community students. Hoo Jo Hong (2001) conducted a research on the arrangement operation method for general high school educational process, and it was found out that the general choice subjects were excessively weighty and lacked sequences, hence easily ignored in general high school classes. The appointed selection of Education Office and schools resulted in not being able to provide practical decision. In conclusion, in order to accommodate various student requests with limited school resources, it was proposed that an establishment of integrated operation system of teachers and division of role of educational programs among schools.

\section{Research Methods}

\subsection{Literature Investigation}

Based on the 2015 Reformed Educational Process, related data and preliminary research, data was collected and analyzed thoroughly, and found the implications for the future 2015 Reformed Educational Process policy. Also, information on liberal arts and natural sciences 
combined type educational process provided by the Ministry of Education was explored and through literature investigation and foreign examples, researched the liberal arts and natural sciences combination cases.

Through such literature data, recent data on 2015 Reformed Educational Process policy and applicability was gathered, and through the questionnaire on students and interviews on teachers based on the data, perception and analysis on status on the reformed educational process was obtained. Also, student questionnaires and teachers interview questions were developed centrally on the main policy of the reformed educational process, including liberal arts and natural sciences combination policy, free-semester system, career education, in order to understand the detailed contents.

\subsection{Students Questionnaire Investigation}

Questionnaire investigation on the topic of 'teenage perception research on liberal arts and natural sciences combination' was conducted from 2016 2017 to total 306 male and female students of 1st and 2nd year of junior high schools in Jeolla Book Do area, including A general junior high school (Ham Yeol girls junior high school, Private), B autonomous junior high school (Hwa San junior high school, Private) and C autonomous junior high school (Hoi Hyun junior high school, Public). These 3 junior high school are all located in rural areas. 2 of the junior high schools are appointed as autonomous junior high school, aiming to implement initiating educational process in that area. Through the comparison of these junior high schools, this research aims to discover how efficiently general and autonomous junior high schools prepared to the 2015 Reformed Educational Process.

Through the research by written techniques of structured questionnaire on the students' perception on liberal arts and natural sciences combination integration, agreement or disagreement decisions and its cause, route of awareness, conduction purpose, detailed contents of operation of the educational process and satisfactory rate, and sampling by school, gender and grade, the corresponding value was extracted.

\subsection{Teacher Interviews}

Interviews on teachers were conducted to investigate whether the teachers deliver the reformed educational process to the students and their opinion on liberal arts and natural sciences combination and free-semester system, etc. Taking into account of the purpose of the research on figuring out the perception on the reformed educational process, teachers in charge of various grades and subjects were included. List of teachers participated in the survey are presented in the Table 1. 


\section{Macrothink}

Global Journal of Educational Studies

ISSN 2377-3936

2019, Vol. 5, No. 1

Table 1. List of interviewed teachers

\begin{tabular}{|c|c|c|c|c|c|}
\hline Name & School & $\begin{array}{c}\text { Grade in } \\
\text { charge }\end{array}$ & Subject & $\begin{array}{c}\text { Pros and Cons } \\
\text { (on the liberal arts and } \\
\text { natural sciences } \\
\text { combination policy) }\end{array}$ & $\begin{array}{c}\text { Satisfaction / } \\
\text { Dissatisfaction } \\
\text { (free-semester } \\
\text { system) }\end{array}$ \\
\hline Kwon & C & $\begin{array}{c}\text { Second year } \\
\text { student }\end{array}$ & Society & Pros & Satisfaction \\
\hline Lim & C & $\begin{array}{c}\text { Second year } \\
\text { student }\end{array}$ & $\begin{array}{c}\text { Technology and } \\
\text { home economics }\end{array}$ & Pros & Satisfaction \\
\hline Lee & C & $\begin{array}{c}\text { First year } \\
\text { student }\end{array}$ & Science & Pros & Satisfaction \\
\hline Ha & B & $\begin{array}{c}\text { Third year } \\
\text { student }\end{array}$ & Mathematics & Pros & Need to revision \\
\hline Jeong & B & $\begin{array}{c}\text { Second year } \\
\text { student }\end{array}$ & Morality & Pros & Nissatisfaction \\
\hline Lee & B & $\begin{array}{c}\text { Third year } \\
\text { student }\end{array}$ & $\begin{array}{c}\text { Korean } \\
\text { (national language }\end{array}$ & Pros & Need to revision \\
\hline Jeong & B & - & Mathematics & Pros & \\
\hline
\end{tabular}

Through these, the research aims to seek for future efficient application of the reformed educational process in the rural areas for the features of the 2015 Reformed Educational Process, including the liberal arts and natural sciences combination policy, free-semester system and career education.

\section{Research Results}

The research results on the response of students on the liberal arts and natural sciences combination policy, free-semester system and career education in the 2015 Reformed Educational Process appeared as follows.

\subsection{Perception on Liberal Arts and Natural Sciences Combination and Free-Semester System}

In the free-semester system preference investigation, majority of the students responded positively to the conduction of free-semester system, and less than $10 \%$ disagreed to it. Especially in $\mathrm{C}$ autonomous public junior high school, very good response exceeded more than half and more than $80 \%$ responded good to it. In overall, in conducting free-semester system, it could be seen that the targeted students showed positive response. 
Table 2. Free-semester system preference investigation

\begin{tabular}{|c|c|c|c|c|c|c|}
\hline School & Very bad & Bad & Normal & Good & Very Good & Sum \\
\hline \multirow{2}{*}{ A School } & 4 & 11 & 34 & 13 & 2 & 64 \\
\cline { 2 - 7 } & $6.3 \%$ & $17.2 \%$ & $53.1 \%$ & $20.3 \%$ & $3.1 \%$ & $100.0 \%$ \\
\hline \multirow{2}{*}{ B School } & 2 & 5 & 12 & 8 & 17 & 44 \\
\cline { 2 - 7 } & $4.5 \%$ & $11.4 \%$ & $27.3 \%$ & $18.2 \%$ & $38.6 \%$ & $100.0 \%$ \\
\hline \multirow{2}{*}{ C School } & 0 & 4 & 19 & 52 & 87 & 162 \\
\cline { 2 - 7 } & $0.0 \%$ & $2.5 \%$ & $11.7 \%$ & $32.1 \%$ & $53.7 \%$ & $100.0 \%$ \\
\hline \multirow{3}{*}{ Sum } & $\mathbf{6}$ & $\mathbf{2 0}$ & $\mathbf{6 5}$ & $\mathbf{7 3}$ & $\mathbf{1 0 6}$ & $\mathbf{2 7 0}$ \\
\cline { 2 - 7 } & $\mathbf{2 . 2 \%}$ & $\mathbf{7 . 4 \%}$ & $\mathbf{2 4 . 1 \%}$ & $\mathbf{2 7 . 0 \%}$ & $\mathbf{3 9 . 3 \%}$ & $\mathbf{1 0 0 . 0 \%}$ \\
\hline
\end{tabular}

Students answered that the route of knowing about liberal arts and natural sciences combination policy was mostly through teachers, parents, friends and the Internet. Mostly knew trough their parents, then teachers, but in A 'general junior high school' highest percentage was knowledge route 'through friends.' There was gap in knowledge route of parents and friends in schools, but the teacher response was around $25 \%$ of even distribution among the schools. This can be analyzed that the interests of parents are bigger in autonomous junior high schools than general junior high schools.

Table 3. Route of knowing about the liberal arts and natural sciences combination policy (multiple choice)

\begin{tabular}{|c|c|c|c|c|c|c|}
\hline & Teacher & Parents & Friends & Internet, SNS & Others & Sum \\
\hline \multirow{2}{*}{ A School } & 13 & 10 & 16 & 8 & 4 & 51 \\
& $(25.5 \%)$ & $(19.6 \%)$ & $(31.4 \%)$ & $(15.7 \%)$ & $(7.8 \%)$ & $(100 \%)$ \\
\hline \multirow{2}{*}{ B School } & 23 & 34 & 13 & 15 & 6 & 91 \\
& $(25.3 \%)$ & $(37.4 \%)$ & $(14.3 \%)$ & $(16.5 \%)$ & $(6.6 \%)$ & $(100 \%)$ \\
\hline \multirow{2}{*}{ C School } & 50 & 51 & 41 & 37 & 19 & 198 \\
& $(25.3 \%)$ & $(25.8 \%)$ & $(20.7 \%)$ & $(18.7 \%)$ & $(9.6 \%)$ & $(100 \%)$ \\
\hline \multirow{2}{*}{ Sum } & $\mathbf{8 6}$ & $\mathbf{9 5}$ & $\mathbf{7 0}$ & $\mathbf{6 0}$ & $\mathbf{2 9}$ & $\mathbf{3 4 0}$ \\
& $\mathbf{( 2 5 . 3 \% )}$ & $\mathbf{( 2 7 . 9 \% )}$ & $\mathbf{( 2 0 . 6 \%}$ & $\mathbf{( 1 7 . 7 \%}$ & $(\mathbf{8 . 5 \%}$ & $\mathbf{( 1 0 0 \% )}$ \\
\hline
\end{tabular}

In the perception investigation of the students on the liberal arts and natural sciences combination purpose, the biggest purpose was found out to be nurturing the competence required by the future society. Next purpose was 'obtaining basic knowledge of humanities, social and scientific technologies' and 'student-oriented educational process to allow students to express dreams and talents.' This shows that the students recognize liberal arts and natural sciences combination purpose as not only improving the current policy but also as a crucial education process to prepare for the upcoming future society. The number of students in the higher-grade boundaries was particularly larger of $41.18 \%$ who answered 'future society 
required competence cultivation' as the purpose. Hence, it can be seen that the liberal arts and natural sciences combination is expected to be the suitable educational process to prepare for the upcoming knowledge economic society. Also, the students in average and lower grades boundaries answered mostly that the purpose if for the operation of student-oriented educational process to allow students to express dreams and talents, recording $30.8 \%$ and $39.1 \%$. Although the perception shows slight perceptional difference with the higher-grade students, the students showed positive expectations in general. Particularly for the purpose of liberal arts and natural sciences combination purpose, higher-grade students anticipate preparation for the future society and the students in average and lower grades boundaries recognize the purpose as educational process to manifest dreams and talents of the students accordingly. Lastly, 'improving classroom teaching and evaluation system establishment' recorded the lowest in overall, but the lower grade students relatively chose more of $26.1 \%$, raising the need to grow perception consistently for these students to prepare for the future society.

Table 4. Perception investigation of the students on the liberal arts and natural sciences combination policy (multiple choice)

\begin{tabular}{|c|c|c|c|c|c|c|}
\hline & $\begin{array}{c}\text { Obtaining } \\
\text { basic } \\
\text { knowledge of } \\
\text { humanities, } \\
\text { social and } \\
\text { scientific } \\
\text { technologies }\end{array}$ & $\begin{array}{l}\text { Student-oriented } \\
\text { educational } \\
\text { process to allow } \\
\text { students to } \\
\text { express dreams } \\
\text { and talents }\end{array}$ & $\begin{array}{c}\text { Found out to } \\
\text { be nurturing } \\
\text { the } \\
\text { competence } \\
\text { required by } \\
\text { the future } \\
\text { society }\end{array}$ & $\begin{array}{l}\text { Improving } \\
\text { classroom } \\
\text { teaching and } \\
\text { evaluation } \\
\text { system } \\
\text { establishment }\end{array}$ & Others & Sum \\
\hline $\begin{array}{c}\text { Higher-grade } \\
\text { students }\end{array}$ & $\begin{array}{c}44 \\
(28.8 \%)\end{array}$ & $\begin{array}{c}27 \\
(17.7 \%)\end{array}$ & $\begin{array}{c}63 \\
(41.2 \%)\end{array}$ & $\begin{array}{c}5 \\
(3.3 \%) \\
\end{array}$ & $\begin{array}{c}14 \\
(9.2 \%) \\
\end{array}$ & $\begin{array}{c}153 \\
(100 \%)\end{array}$ \\
\hline $\begin{array}{c}\text { Average } \\
\text { grade students }\end{array}$ & $\begin{array}{c}36 \\
(27.1 \%)\end{array}$ & $\begin{array}{c}41 \\
(30.8 \%)\end{array}$ & $\begin{array}{c}36 \\
(27.1 \%)\end{array}$ & $\begin{array}{c}7 \\
(5.3 \%) \\
\end{array}$ & $\begin{array}{c}13 \\
(9.8 \%) \\
\end{array}$ & $\begin{array}{c}133 \\
(100 \%)\end{array}$ \\
\hline $\begin{array}{c}\text { Lower grade } \\
\text { students }\end{array}$ & $\begin{array}{c}1 \\
(4.4 \%)\end{array}$ & $\begin{array}{c}9 \\
(39.1 \%)\end{array}$ & $\begin{array}{c}5 \\
(21.7 \%)\end{array}$ & $\begin{array}{c}6 \\
(26.1 \%)\end{array}$ & $\begin{array}{c}2 \\
(8.7 \%) \\
\end{array}$ & $\begin{array}{c}23 \\
(100 \%)\end{array}$ \\
\hline Sum & $\begin{array}{c}81 \\
(26.2 \%)\end{array}$ & $\begin{array}{c}77 \\
(24.9 \%)\end{array}$ & $\begin{array}{c}104 \\
(33.7 \%)\end{array}$ & $\begin{array}{c}18 \\
(5.8 \%)\end{array}$ & $\begin{array}{c}29 \\
(9.4 \%)\end{array}$ & $\begin{array}{c}309 \\
(100 \%)\end{array}$ \\
\hline
\end{tabular}

For the students who responded if they agreed with the liberal arts and natural sciences combination, yes or no answers differed in schools but showed similar ratio in overall. In detail, 'disagreement (37.5\%)' and 'I don't know (43.8\%)' was higher in general than autonomous junior high schools. This shows lack of certainty in extent of advantage for the future admissions or career activity regarding the liberal arts and natural sciences combination yet. Also, general junior high school students showed such traits more strongly than the autonomous junior high school students. This shows the continuous need on the explanation on the appropriateness regarding the liberal arts and natural sciences combination policy. 
Table 5. Pros and Cons on the liberal arts and natural sciences combination policy

\begin{tabular}{|c|c|c|c|c|}
\hline & Agreement & Disagreement & Do not know & Sum \\
\hline \multirow{2}{*}{ A School } & 12 & 24 & 28 & 64 \\
& $(18.8 \%)$ & $(37.5 \%)$ & $(43.8 \%)$ & $(100.0 \%)$ \\
\hline \multirow{2}{*}{ B School } & 25 & 25 & 28 & 78 \\
& $(32.1 \%)$ & $(32.1 \%)$ & $(35.9 \%)$ & $(100.0 \%)$ \\
\hline \multirow{2}{*}{ C School } & 71 & 45 & 45 & 161 \\
& $(44.1 \%)$ & $(28.0 \%)$ & $(28.0 \%)$ & $(100.0 \%)$ \\
\hline \multirow{2}{*}{ Sum } & $\mathbf{1 0 6}$ & $\mathbf{9 5}$ & $\mathbf{1 0 2}$ & $\mathbf{3 0 3}$ \\
& $(\mathbf{3 5 . 0 \%})$ & $\mathbf{( 3 1 . 4 \% )}$ & $\mathbf{( 3 3 . 7 \% )}$ & $\mathbf{( 1 0 0 . 0 \% )}$ \\
\hline
\end{tabular}

In the survey on the agreement of the liberal arts and natural sciences combination, the biggest reason for agreement was 'because it gives wide range of choices for one's path', recording $63.0 \%$ among the students whom agreed. The next highest response was 'for those who do not know their propensity', of 20.4\%. The biggest reason for disagreement was 'due to increase in subjects that must be learned', recording $35.1 \%$ among the students whom disagreed and 'because I have to learn the subject that I am not confident in' was also high, recording $30.4 \%$ of the responses. Those who responded, 'I don't know', the biggest reason was that 'I don't know the possible influences resulted from the implementation of the liberal arts and natural sciences combination', recording 51.5\%. 'Because I don't know how the liberal arts and natural sciences combination is implemented' recorded second highest of $35.6 \%$, hence pointing the need for guiding curriculum process integration.

Table 6. Survey on the agreement of the liberal arts and natural sciences combination

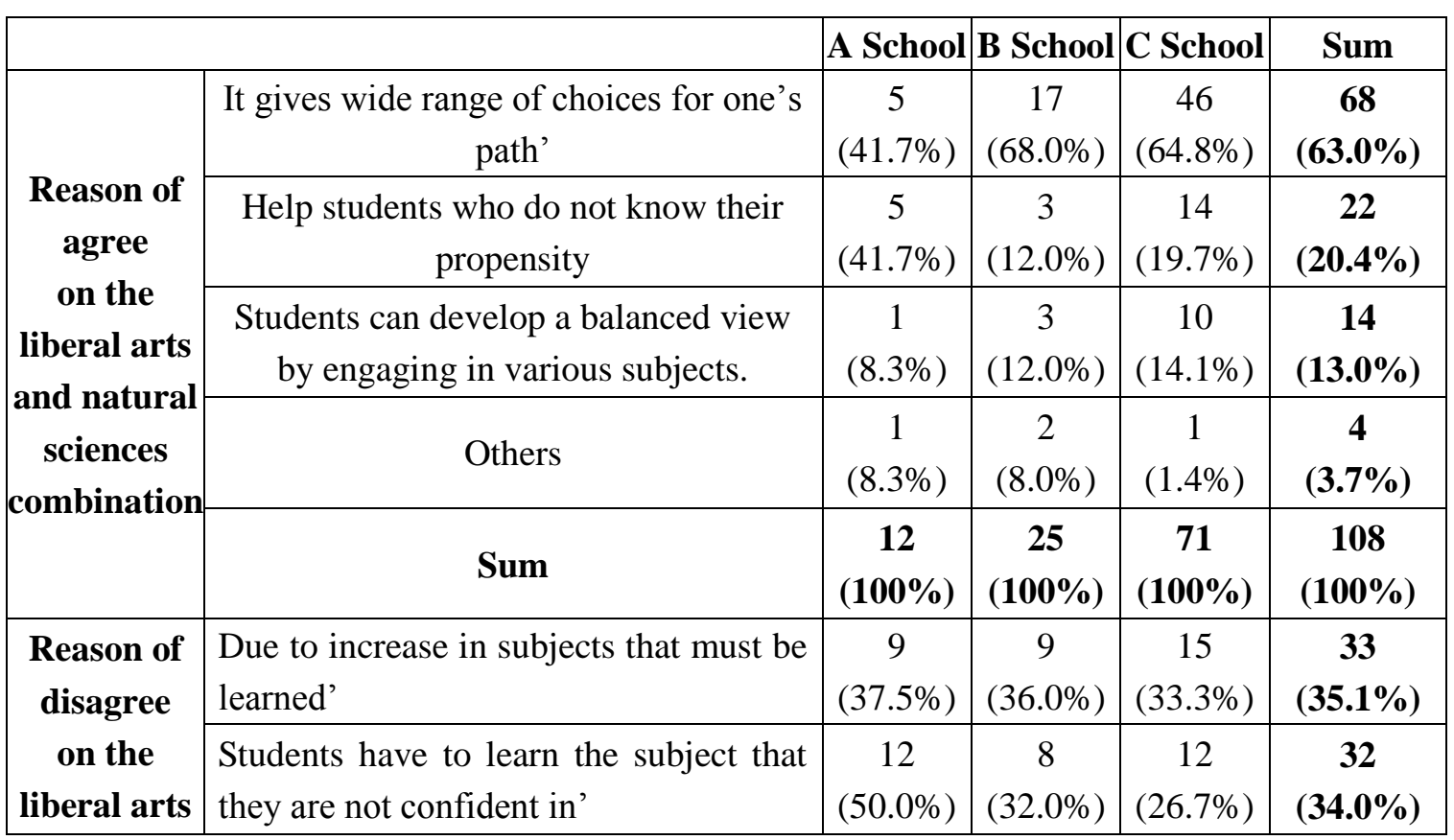




\begin{tabular}{|c|c|c|c|c|c|}
\hline \multirow[t]{3}{*}{$\begin{array}{c}\text { and natural } \\
\text { sciences } \\
\text { combination }\end{array}$} & $\begin{array}{l}\text { Due to differences with current } \\
\text { education system, there will be } \\
\text { confusion in class }\end{array}$ & $\begin{array}{c}2 \\
(8.3 \%)\end{array}$ & $\begin{array}{c}7 \\
(28.0 \%)\end{array}$ & $\begin{array}{c}10 \\
(22.2 \%)\end{array}$ & $\begin{array}{c}19 \\
(20.2 \%)\end{array}$ \\
\hline & Others & $\begin{array}{c}1 \\
(4.2 \%)\end{array}$ & $\begin{array}{c}1 \\
(4.0 \%)\end{array}$ & $\begin{array}{c}8 \\
(17.8 \%)\end{array}$ & $\begin{array}{c}10 \\
(10.6 \%)\end{array}$ \\
\hline & Sum & $\begin{array}{c}24 \\
(100 \%)\end{array}$ & $\begin{array}{c}25 \\
(100 \%)\end{array}$ & $\begin{array}{c}45 \\
(100 \%)\end{array}$ & $\begin{array}{c}94 \\
(100 \%)\end{array}$ \\
\hline \multirow{5}{*}{$\begin{array}{c}\text { Reason of } \\
\text { do not know }\end{array}$} & $\begin{array}{l}\text { Because I don't know how the liberal } \\
\text { arts and natural sciences combination is } \\
\text { implemented' }\end{array}$ & $\begin{array}{c}13 \\
(46.4 \%)\end{array}$ & $\begin{array}{c}7 \\
(25.0 \%)\end{array}$ & $\begin{array}{c}16 \\
(35.6 \%)\end{array}$ & $\begin{array}{c}36 \\
(35.6 \%)\end{array}$ \\
\hline & $\begin{array}{l}\text { I do not think there will be any big } \\
\text { difference. }\end{array}$ & $\begin{array}{c}1 \\
(3.6 \%)\end{array}$ & $\begin{array}{c}4 \\
(14.3 \%)\end{array}$ & $\begin{array}{c}5 \\
(11.1 \%)\end{array}$ & $\begin{array}{c}10 \\
(9.9 \%)\end{array}$ \\
\hline & $\begin{array}{l}\text { I don't know the possible influences } \\
\text { resulted from the implementation of the } \\
\text { liberal arts and natural sciences } \\
\text { combination' }\end{array}$ & $\begin{array}{c}13 \\
(46.4 \%)\end{array}$ & $\begin{array}{c}17 \\
(60.7 \%)\end{array}$ & $\begin{array}{c}22 \\
(48.9 \%)\end{array}$ & $\begin{array}{c}52 \\
(51.5 \%)\end{array}$ \\
\hline & Others & $\begin{array}{c}1 \\
(3.6 \%) \\
\end{array}$ & $\begin{array}{c}0 \\
(0.0 \%)\end{array}$ & $\begin{array}{c}2 \\
(4.4 \%) \\
\end{array}$ & $\begin{array}{c}3 \\
(3.0 \%) \\
\end{array}$ \\
\hline & Sum & $\begin{array}{c}28 \\
(100 \%)\end{array}$ & $\begin{array}{c}28 \\
(100 \%)\end{array}$ & $\begin{array}{c}45 \\
(100 \%)\end{array}$ & $\begin{array}{c}101 \\
(100 \%)\end{array}$ \\
\hline
\end{tabular}

In conclusion, the biggest reason for agreeing with the liberal arts and natural sciences combination is 'because it gives wide range of choices for one's path', which the response is connected with the student's path, whereas the biggest reason for opposing the liberal arts and natural sciences combination was 'due to increase in subjects that must be learned' or 'because I have to learn the subject that I am not confident in', which was found out to be resulting from academic pressure.

\subsection{Career Education Recognition in the Reformed Educational Process}

In asking questions on perception on career educational process, those who responded 'I know' to career educational process which allows students to 'choose and complete various courses depending on their path and aptitude' slightly exceeded half by $52.46 \%$, but those who doesn't know about it also recorded 47.5\%. Also, on whether there is a module arrangement guide provided to help the students to choose modules depending on their path, more than half of $57.9 \%$ answered 'no' to it and regarding the career educational process of 'rearranging the number of modules per semester or focusing on the course details of concentrated course system over a particular period' was only answered 'yes' by $31.135 \%$, which is low. Lastly, regarding the career educational process, 'optional modules are divided into 'general choice' and 'career choice" was only 'known' by only $41.78 \%$, which is less than half of the students. In the overall recognition on the career educational procedure, student recognition turned out to be insufficient widely. This points out the need for efforts in 
notifying the policy direction in order to effectively apply the career educational process.

Table 7. Perception on career educational curriculum

\begin{tabular}{|c|c|c|c|c|c|}
\hline & & School A & School B & School C & Sum \\
\hline \multirow{2}{*}{$\begin{array}{l}\text { Allows students to 'choose and complete } \\
\text { various courses depending on their path and } \\
\text { aptitude' }\end{array}$} & I know & $\begin{array}{c}38 \\
(59.4 \%)\end{array}$ & $\begin{array}{c}51 \\
(63.8 \%)\end{array}$ & $\begin{array}{c}71 \\
(44.1 \%)\end{array}$ & $\begin{array}{c}160 \\
(52.5 \%)\end{array}$ \\
\hline & $\begin{array}{l}\text { I don't } \\
\text { know }\end{array}$ & $\begin{array}{c}26 \\
(40.6 \%)\end{array}$ & $\begin{array}{c}29 \\
(36.3 \%)\end{array}$ & $\begin{array}{c}90 \\
(55.9 \%)\end{array}$ & $\begin{array}{c}145 \\
(47.5 \%)\end{array}$ \\
\hline \multirow{2}{*}{$\begin{array}{l}\text { There is a module arrangement guide } \\
\text { provided to help the students to choose } \\
\text { modules depending on their path }\end{array}$} & I know & $\begin{array}{c}34 \\
(53.1 \%) \\
\end{array}$ & $\begin{array}{c}41 \\
(51.9 \%) \\
\end{array}$ & $\begin{array}{c}53 \\
(32.9 \%) \\
\end{array}$ & $\begin{array}{c}128 \\
(42.1 \%) \\
\end{array}$ \\
\hline & $\begin{array}{l}\text { I don't } \\
\text { know }\end{array}$ & $\begin{array}{c}30 \\
(46.9 \%)\end{array}$ & $\begin{array}{c}38 \\
(48.1 \%)\end{array}$ & $\begin{array}{c}108 \\
(67.1 \%)\end{array}$ & $\begin{array}{c}176 \\
(57.9 \%)\end{array}$ \\
\hline \multirow{2}{*}{$\begin{array}{l}\text { Rearrange the number of modules per } \\
\text { semester or focusing on the course details of } \\
\text { concentrated course system over a particular } \\
\text { period' }\end{array}$} & I know & $\begin{array}{c}27 \\
(42.2 \%)\end{array}$ & $\begin{array}{c}28 \\
(35.4 \%)\end{array}$ & $\begin{array}{c}40 \\
(24.7 \%)\end{array}$ & $\begin{array}{c}95 \\
(31.2 \%)\end{array}$ \\
\hline & $\begin{array}{l}\text { I don't } \\
\text { know }\end{array}$ & $\begin{array}{c}37 \\
(57.8 \%)\end{array}$ & $\begin{array}{c}51 \\
(64.6 \%)\end{array}$ & $\begin{array}{c}122 \\
(75.3 \%)\end{array}$ & $\begin{array}{c}210 \\
(68.9 \%)\end{array}$ \\
\hline \multirow{2}{*}{$\begin{array}{l}\text { Optional modules are divided into 'general } \\
\text { choice' and 'career choice' }\end{array}$} & I know & $\begin{array}{c}33 \\
(51.6 \%) \\
\end{array}$ & $\begin{array}{c}39 \\
(49.4 \%) \\
\end{array}$ & $\begin{array}{c}55 \\
(34.7 \%) \\
\end{array}$ & $\begin{array}{c}127 \\
(41.9 \%) \\
\end{array}$ \\
\hline & $\begin{array}{l}\text { I don't } \\
\text { know }\end{array}$ & $\begin{array}{c}31 \\
(48.4 \%)\end{array}$ & $\begin{array}{c}40 \\
(50.6 \%)\end{array}$ & $\begin{array}{c}106 \\
(65.8 \%)\end{array}$ & $\begin{array}{c}177 \\
(58.2 \%)\end{array}$ \\
\hline
\end{tabular}

For the criteria of 'choose and complete various courses depending on their path and aptitude', the students who answered 'good' and 'very good' recorded $32.5 \%$ and $29.8 \%$ respectively, amounting more than $60 \%$ of the students. For 'there is a module arrangement guide provided to help the students to choose modules depending on their path', the students who answered 'good' and 'very good' recorded $31.5 \%$ and $23.0 \%$ respectively, amounting more than half of the students. For 'rearranging the number of modules per semester or focusing on the course details of concentrated course system over a particular period', the students who answered 'good' and 'very good' recorded $11.5 \%$ and $20.7 \%$ respectively, showing relatively lower rate. For 'optional modules are divided into 'general choice' and 'career choice", the students who answered 'good' and 'very good' recorded $22.3 \%$ and $28.9 \%$ respectively, amounting around half the students. 
Table 8. Preference survey on career educational curriculum

\begin{tabular}{|c|c|c|c|c|c|}
\hline & & A School & B School & C School & Sum \\
\hline \multirow{6}{*}{$\begin{array}{l}\text { Allows students to } \\
\text { 'choose and complete } \\
\text { various courses } \\
\text { depending on their } \\
\text { path and aptitude' }\end{array}$} & Very Good & $15(23.4 \%)$ & $29(36.7 \%)$ & $55(34.0 \%)$ & $99(32.5 \%)$ \\
\hline & Good & $20(31.3 \%)$ & $23(29.1 \%)$ & $48(29.6 \%)$ & $91(29.8 \%)$ \\
\hline & Normal & $27(42.2 \%)$ & $24(30.4 \%)$ & $55(34.0 \%)$ & $106(34.8 \%)$ \\
\hline & $\mathrm{Bad}$ & $2(3.1 \%)$ & $0(0.0 \%)$ & $1(0.6 \%)$ & $3(1.0 \%)$ \\
\hline & Very Bad & $0(0.0 \%)$ & $3(3.8 \%)$ & $3(1.9 \%)$ & $6(2.0 \%)$ \\
\hline & Sum & $64(100 \%)$ & $79(100 \%)$ & $162(100 \%)$ & $305(100 \%)$ \\
\hline \multirow{6}{*}{$\begin{array}{l}\text { There is a module } \\
\text { arrangement guide } \\
\text { provided to help the } \\
\text { students to choose } \\
\text { modules depending } \\
\text { on their path }\end{array}$} & Very Good & $12(18.8 \%)$ & $30(38.0 \%)$ & $54(33.3 \%)$ & $96(31.5 \%)$ \\
\hline & Good & $17(26.6 \%)$ & $14(17.7 \%)$ & $39(24.1 \%)$ & $70(23.0 \%)$ \\
\hline & Normal & $32(50.0 \%)$ & $31(39.2 \%)$ & $62(38.3 \%)$ & $125(41.0 \%)$ \\
\hline & $\mathrm{Bad}$ & $3(4.7 \%)$ & $2(2.5 \%)$ & $3(1.9 \%)$ & $8(2.6 \%)$ \\
\hline & Very Bad & $0(0.0 \%)$ & $2(2.5 \%)$ & $4(2.5 \%)$ & $6(2.0 \%)$ \\
\hline & Sum & $64(100 \%)$ & $79(100 \%)$ & $162(100 \%)$ & $305(100 \%)$ \\
\hline \multirow{6}{*}{$\begin{array}{c}\text { Rearrange the } \\
\text { number of modules } \\
\text { per semester or } \\
\text { focusing on the } \\
\text { course details of } \\
\text { concentrated course } \\
\text { system over a } \\
\text { particular period' }\end{array}$} & Very Good & $4(6.3 \%)$ & $14(17.7 \%)$ & $17(10.5 \%)$ & $35(11.5 \%)$ \\
\hline & Good & $19(29.7 \%)$ & $13(16.5 \%)$ & $31(19.1 \%)$ & $63(20.7 \%)$ \\
\hline & Normal & $37(57.8 \%)$ & $45(57.0 \%)$ & $81(50.0 \%)$ & $163(53.4 \%)$ \\
\hline & $\mathrm{Bad}$ & $3(4.7 \%)$ & $1(1.3 \%)$ & $22(13.6 \%)$ & $26(8.5 \%)$ \\
\hline & Very Bad & $1(1.6 \%)$ & $6(7.6 \%)$ & $11(6.8 \%)$ & $18(5.9 \%)$ \\
\hline & Sum & $64(100 \%)$ & $79(100 \%)$ & $162(100 \%)$ & $305(100 \%)$ \\
\hline \multirow{6}{*}{$\begin{array}{l}\text { Optional modules are } \\
\text { divided into 'general } \\
\text { choice' and 'career } \\
\text { choice' }\end{array}$} & Very Goo & $6(9.4 \%)$ & $21(26.6 \%)$ & $41(25.3 \%)$ & $68(22.3 \%)$ \\
\hline & Good & $25(39.1 \%)$ & $25(31.6 \%)$ & $38(23.5 \%)$ & $88(28.9 \%)$ \\
\hline & Normal & $29(45.3 \%)$ & $30(38.0 \%)$ & $73(45.1 \%)$ & $132(43.3 \%)$ \\
\hline & $\mathrm{Bad}$ & $3(4.7 \%)$ & $1(1.3 \%)$ & $5(3.1 \%)$ & $9(3.0 \%)$ \\
\hline & Very Bad & $1(1.6 \%)$ & $2(2.5 \%)$ & $5(3.1 \%)$ & $8(2.6 \%)$ \\
\hline & Sum & $64(100 \%)$ & $79(100 \%)$ & $162(100 \%)$ & $305(100 \%)$ \\
\hline
\end{tabular}

This shows that the career educational process is recognized positively by most students in overall. However, considering the students who are unaware of the process, active promotion and guidance on the career educational process is essential, and through these, positive responses can be anticipated.

\subsection{Teacher Interview on the Reformed Educational Process}

For the liberal arts and natural sciences combination, all teachers indicated a positive stance. The reasons for agreement include 'widening of thinking', 'diversification of range of choices', 'reduction in biasness in either liberal arts or natural sciences', 'enhancing academic performance' and 'connection with career path'. Regarding the recognition on the liberal arts and natural sciences combination, most teachers responded to know about it, but there was 
also response that they do not know about it in detail. About the liberal arts and natural sciences combination, only 1 out of 7 teachers knew about it through training and the remaining knew from the media or

\subsubsection{Widening of Thinking and Diversification of Range of Choices Expectations}

First, the teachers who participated in the interview responded that the 2015 educational process provides diversification of range of choices and widens thinking of the students. They especially had expectations on the reformed educational process providing various thinking areas that are necessary in life.

While burden on the number of modules can be reduced, humanities knowledge can also be obtained to widen the range of opportunities, and through the liberal arts and natural sciences combination, it is good that there is more time to make decisions. (Teacher Lim, C School, Technology and home economics)

It will be easier to make choices for university major or follow university education if certain level of fundamental advanced part of math without separating liberal arts and natural sciences subjects up to high school education. Also, range of choice is limited due to the division in the liberal arts and natural sciences.

(Teacher Ha, B School, Mathematics)

\subsubsection{Reduction in Biasness in Either Liberal Arts or Natural Sciences}

The second for agreeing with the reformed educational process is reduction in biasness in either liberal arts or natural sciences. Teachers had opinions that the existing division in liberal arts and natural sciences can restrict the career path choices for students and anticipated that the reformed educational process will have a very big role for preparing for the future society.

Natural sciences and liberal arts are taught in their own ways, hence liberal arts students often give up on math and science students struggle to write essays etc, hence reducing the scope of thinking, needing an integration.

(Teacher Kwon, C School, Society)

I believe that the division is good, but overly one-sided education can be narrow-minded, hence integration could improve the quality of life. Science students can feel inferior to humanities knowledge and vice versa.

(Teacher Lee, C School, Science)

\subsection{3 'Enhancing Academic Performance' and 'Connection with Career Path'}

It was interviewed that the reformed educational process pursuing integrated classes can enhance academic efficiency and strengthen career education, hence influencing positively on the path of the students. It was also interviewed that the unlike the existing subject oriented curriculum education, customizing to the career path of students will allow students to approach the integrated curriculum more flexibly. 
Natural sciences and liberal arts combination reduce the burden of amount of studying and be good to those who avoid natural sciences, and most importantly cuts down waste of time and connect to the career.

$$
\text { (Jeong, B School, Mathematics) }
$$

There was previously an attempt to combine natural sciences and liberal arts in universities and I am glad that it is conducted in high schools, and it is also good in terms of class results and experience.

(Jeong, B School, Morality)

\subsubsection{Concerns on Side Effects of Free-Semester System}

Lastly, concerns on the side effects of free-semester system in the reformed educational process turned out to be big. Mostly agreed with the possibility and purpose of the free-semester system but worried side effects including 'difficulties in student guidance', 'academically demotivating due to lack of examinations', 'free riding in group projects' etc.

The objective itself that focuses more on experience than textbooks is ideal, but the students tend to focus more on not having examinations than various experiences. (Lee, B School, Korean national language)

I do not agree. Because there are regional differences for career activities, and there are chances of free riding, but I think that freed class activities and lack of burden from examinations can be good. (Jeong, B School, Morality)

I think it will be good. It should have been much earlier, but the disadvantage is that students cannot differentiate between freedom and autonomy. They treat them as equal, hence thinking that no exams mean playing. (Kwon, C School, Society)

It was slightly more difficult to instruct subjects to connect with careers and conduct classes more actively but found students who found more interest in classes. It was physically tiring at times to conduct classes while carrying out free-semester activities, and removal of exams led to students to negate their studies and imposed more difficulties on instructing student attitudes. (Jeong, B School, Mathematics)

In conclusion, autonomous junior high school teachers all had positive anticipation towards the reformed educational policy. It could be seen from the interview that they had expectations of the reformed educational process providing wider choices in career and preparation stage of the student's future. Most of the teachers agreed with career education and its advantages but showed concerns on the side effects of free-semester system.

\section{Conclusion}

Up until now, the high school education set the division of natural sciences and liberal arts as its foundation. Also, the decision on natural sciences and liberal arts acted as the turning point for career path direction. In such background, 2nd year high school students had to choose life-changing decision on natural sciences and liberal arts. This is choosing the subjects and 
curriculum to study more centrally between natural sciences and liberal arts through the choice in the subject they intend to study. Hence, it is not easy for students to choose the most appropriate subjects depending on their personality, mindset, interests and aptitude, merely a year after entering the high school and pushed in situation of university admissions, hence they are not able to sufficiently consider their career paths nor have experience. Also, changing into another subject due to change in direction will also come as a great burden for the students.

Also, where the students do not have a clear career path set yet, decisions on natural sciences and liberal arts may lead to a different path unlike what they intended. Hence, high school students need to think in depth and need structured preparation for career, but it could not be achieved in the current educational process of the intense university admissions process. In such situation, the 2015 Reformed Educational Process centrally focuses on improving natural sciences and liberal arts policies through the combined type educational process of the natural sciences and liberal arts and pursuing method of implementation. Hence, survey research was done on free-semester system policy, natural sciences and liberal arts integration policy, and career education policy of the 2015 Reformed Educational Process. Perception of students in the rural areas regarding educational process was explored, and autonomous junior high schools in Jeolla Book Do area, where there is already relatively fluid educational policy is in process in particular.

Analysis on survey is as follows. First, mostly positive response was shown in the free-semester system, needing active application of this. Regardless of private and public junior high schools, more than $80 \%$ of students favored the system and negative opinion resulted less than $10 \%$. This shows the anticipation of rural areas autonomous junior high school students who are already under relatively more autonomous educational process. This also means that the existing pilot implementation of educational policy in the autonomous junior high school brought positive effects, hence more active free-semester system can be considered. However, in the teacher's interview, concerns on side effects, including 'difficulties in student guidance', 'academically demotivating due to lack of examinations', 'free riding in group projects' etc were shown.

Second, responses on combined educational process differed per autonomous junior high school. This shows that they delayed their judgment on how the combination of natural sciences and liberal arts can influence their career. In the survey results, the biggest reason why students responded as 'I don't know' is 'I don't know the possible influences resulted from the implementation of the liberal arts and natural sciences combination' and the number exceeds half the entire students who responded, 'I don't know'. Thus, continuous presentation on justifications for combining natural sciences and liberal arts and follow-up measures must be proceeded to carry out various career activities. Also, the biggest reason for agreeing with the liberal arts and natural science combination is 'because it gives a wide range of choice for one's career' recorded $63.0 \%$, hence it showed that the expectations for career and admissions activities in liberal arts and natural science combination policy is big. On the contrary, the biggest reason for disagreement was 'due to increase in subjects that must be learned', recording $35.1 \%$ among the students whom disagreed and 'because I have 
to learn the subject that I am not confident in' was also high, recording $30.4 \%$ of the responses, showing that academic burden as the biggest concern.

Third, in the survey for career educational process, more than half of the students did not know about the details of career educational process. Thus, it could be known that certainty for career education and specified promotion are essential. Moreover, in the detailed career policy, for the criteria of 'choose and complete various courses depending on their path and aptitude', the students who do not know recorded $47.5 \%$, and the criteria of 'optional modules are divided into 'general choice' and 'career choice" was not recognized by more than half the students.

Based on the survey results, free-semester system implementation, liberal arts and natural sciences combined educational process and strengthening career education of the 2015 Educational process reform are anticipated to bring very positive outcome in deciding life directions, and continuous research and supplement policies on the direction are needed. Continuous observation on the recognition of the details of the 2015 Educational process reform, especially in the student's stand, the acceptor, and active promotion and guide for the students will also be needed.

\section{References}

An, S. Y., \& Lee, K. S. (2009). The Factors associated with Youths' Career Decision Making at the Secondary Education Level and Its Effect. Future Youth Journal, 6(4), 81-99.

Bae, H. J. (2015). The Effects of Curriculum Selection in High School on University Life and Employment in the Labor Market. Journal of Vocational Education \& Training, 18(1), 1-36.

Bae, H. J., \& Park, T. S. (2014). An Economic Analysis of Double Majoring: Focusing on University Graduates. The Journal of Economics and Finance of Education, 23(3), 89-125.

Cho, C. K. (2016). Exploring on the Convergent Curriculum and Thinking based in Geography Subject. The Journal of the Korean Association of Geographic and Environmental Education, 24(3), 47-64. https://doi.org/10.17279/jkagee.2016.24.3.47

Cho, K. H., Choi, J. S., \& Cho, H. S. (2012). High School Students‘ Opinions on Choosing Their Academic Track and Elective Courses for Science and Mathematics. Journal of Research in Curriculum \& Instruction, 16(3), 839-857. https://doi.org/10.24231/rici.2012.16.3.839

Choi, S. H., \& Song, S. H. (1993). Selection of liberal arts and natural sciences for high school students by psychological behavior theory. THE Mathematical Education, 32(4), 389-403.

Gao S. (2015). Comparative study on the policy of integrated curriculum of liberal arts and natural sciences between South Korea and China. Dissertation for a Master Degree, Ewha Womans University.

Hong, H. J. (2001). Instituting Strategies and Provisions for High School Elective Curriculum. The Journal of Curriculum Studies, 19(1), 197-229.

Hong, W. P. (2015). Exploring the Implementation of the 2015 High School Curriculum and Necessary Policy Supports (2015). The Korean Society for Curriculum Studies, 34(2), 69-94. 


\section{$\triangle$ Macrothink}

Global Journal of Educational Studies

ISSN 2377-3936

Hoo, J. H., \& Lim, Y. N. (2014). A study of the development and direction of an integrated curriculum of liberal arts and natural sciences in academic high schools. The Journal of Curriculum Studies, 32(2), 67-99. https://doi.org/10.15708/kscs.32.2.201406.004

Kim, C. W. (2015). Direction of Integrated Curriculum Development in Korean Language Teaching: Chronological Structuralization of Language Curriculum. The Society of Korean Language Education, 148(148), 1-32.

Kim, E. H. (2015). A Study on Disjunction between Ideal and Reality of Social Studies with the Revision of the Integrated Curriculum of Liberal Arts and Natural Sciences: Focused on the Conflict of Integrated Social Studies Curriculum. Research in Social Studies Education, 22(4), 63-78.

Kim, G. H. (2014), A Consideration for Development of Liberal Art and Natural Science Integrated Korean Language Curriculum: Focused on Korean Language Subject Setting Issues. New Korean Language Education, 101(101), 79-112. https://doi.org/10.15734/koed..101.201412.79

Kim, H. H. et al. (2015). The Influence of Dual-major Degree Program on Employment Outcomes of University Graduates. Journal of Vocational Education \& Training, 18(1), 37-70.

Lee, H. J., Lee, K. H. \& Choi, B. S. (2015). Contents Organization of Science Curriculum for the 10th Grade Students Focusing on the Integrated Concepts. Institute of Science Education of Kyungpook $\quad$ National 209-220. https://doi.org/10.21796/jse.2015.39.2.209

Lee, M. M. (2014). In Search of General Education for the 21st Century. Journal of Learner-centered Curriculum and Instruction, 14(11), 285-307.

MOE. (2015). Major Points of the Libral Art and Natural Science Integrated Curriculum. Ministry of Education.

Park, J. D. (2013). Education in Canada with no distinction between Liberal Arts and Natural Sciences. Educational development, 40(4), 50-57.

Yoon, M. S. (2009). Gender Differences in Predicting Academic Course Choices of Middle School Students from Motivational Variables. Korean Journal of Educational Psychology, 23(1), 145-160.

Yeong, H. Y. (2015). A Consideration on Learning Contents of Grammar in 2015 Integrated Liberal Arts-Natural Science Curriculum. Journal of Koreanology, 16, 373-396.

\section{Copyright Disclaimer}

Copyright for this article is retained by the author(s), with first publication rights granted to the journal.

This is an open-access article distributed under the terms and conditions of the Creative Commons Attribution license (http://creativecommons.org/licenses/by/3.0/). 